\title{
Emerging Tourism between Pakistan and China: Tourism Opportunities via China-Pakistan Economic Corridor
}

\author{
Syed Ahtsham $\mathrm{Ali}^{1}$, Jahanzaib Haider ${ }^{2}$, Muhammad $\mathrm{Ali}^{1}$, Syed Irfan $\mathrm{Ali}^{3}$, Xu Ming ${ }^{1}$ \\ ${ }^{1}$ Glorious Sun School of Business and Management, Donghua University, Shanghai, China \\ ${ }^{2}$ Sungkyunkwan University, SKKU Business School, Seoul, South Korea \\ ${ }^{3}$ Quaid-i-Azam University, Islamabad, Pakistan \\ Correspondence: Syed Ahtsham Ali, Glorious Sun School of Business and Management, Donghua University, Shanghai, \\ China.
}

Received: May 27, 2017

doi:10.5539/ibr.v10n8p204

\author{
Accepted: July 12, $2017 \quad$ Online Published: July 21, 2017 \\ URL: https://doi.org/10.5539/ibr.v10n8p204
}

\begin{abstract}
Background: The China-Pakistan Economic Corridor (CPEC) is a mega-project worth more than 54 billion US dollars, as a result of which bilateral relations between Pakistan and China reached new heights. The CPEC is designed to facilitate the establishment of links between Pakistan and the road network, railways and pipelines in conjunction with energy, industrial and other infrastructure projects to ensure the critical energy shortage necessary to enhance the economic growth in Pakistan.

Objective: The main purpose of this article is to shed light on promotion of mutual understanding on China's initiative for the revival of the Silk Road and the benefits and challenges for the tourism industry which the CPEC can bring to the neighboring countries, especially Pakistan. A very new project will give us plenty of room to develop a number of innovative points greatly to improve the quality of services and the overall tourist experience in these new tourist destinations.

Methodology: Qualitative research and analysis with the help of online research and data collection; the study of excellence in individual scenarios tourist sites, focusing on the aspects of service and policy will be useful to improve tourism on both sides via the Silk Road. Authors also collected data from tourist websites and recommend top rated tourist attractions on Silk Road from Khunjrab pass (border between china and Pakistan) to Gawadar, Pakistan. These tourists' attraction are hints for tourists, travel agents and new researchers.
\end{abstract}

Keywords: China-Pakistan economic corridor, tourism industry, tourist attractions, infrastructure development, economic growth

\section{Introduction}

By the start of this century, World is rapidly progressing toward globalization. We already know that almost all the European countries are connected with each other through railways and roads, moreover their easy visa system makes their inhabitants to move from one country to another for study, trade, tourism etc. Same types of agreement are working among American countries e.g. NAFTA. But South-Asia and middle-east is lacking in their connectivity. These connections make the countries to progress hastily and boost their trade and tourism too. What they need is to ameliorate their visa systems and link each other with available means. In this regard China is making progress to connect with different countries through Silk road route. One of the recent advancement made by China is known as China-Pakistan economic corridor (CPEC) which link China especially western part of China from Kashgar to the newly de veloping Gwadar port and middle-eastern countries. Figure 1 explain how this route will lessen the distance of China's trade especially oil import from Gulf countries. This new route reduces this travel distance from about $13000 \mathrm{~km}$ to only $2000 \mathrm{~km}$. 


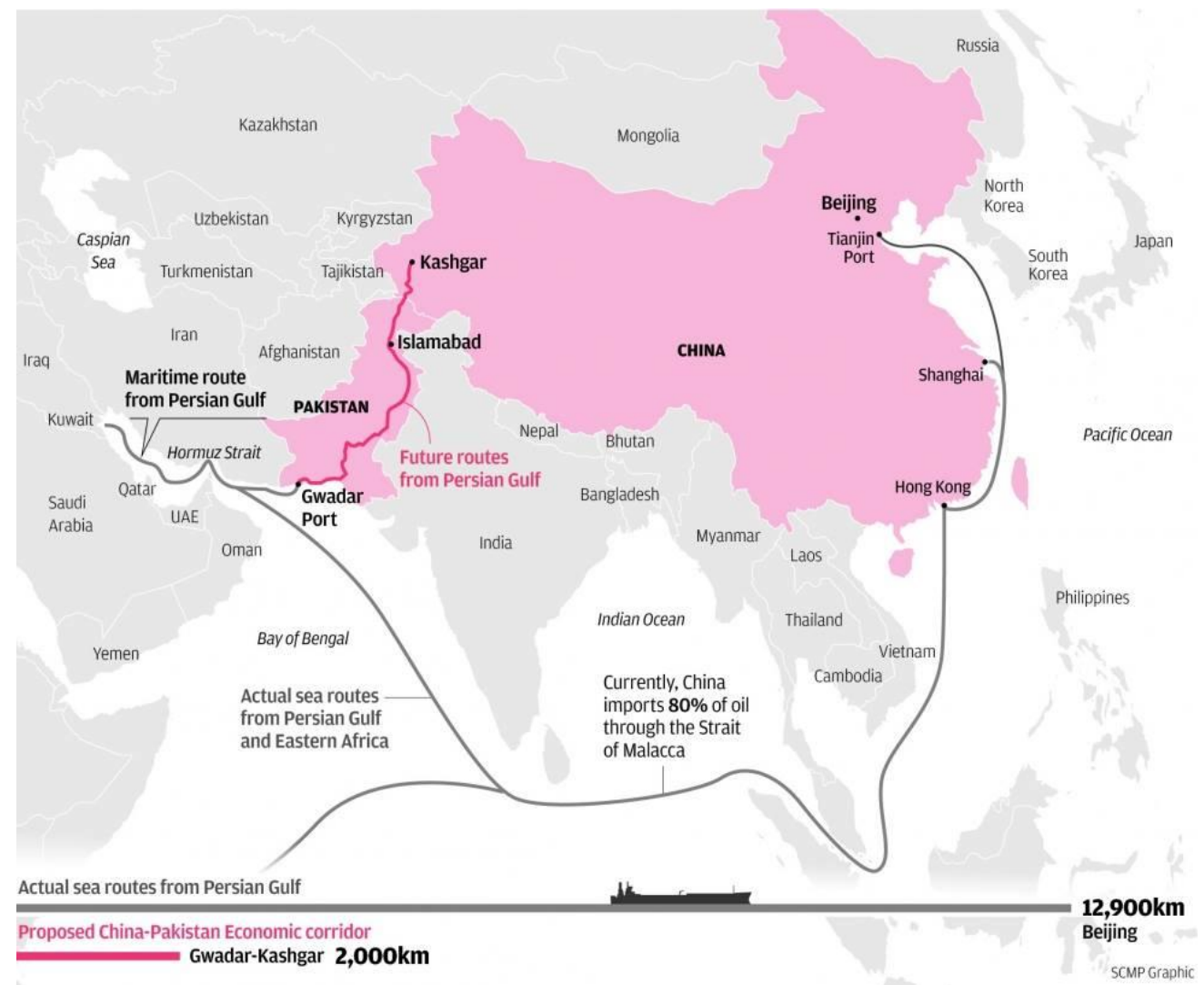

Figure 1. The comparison of new CPEC route to the older route. CPEC will pass through the beautiful Gilgit-Baltistan province which will connect Kashgar in China's western province Xinjiang to rest of the world through Chinese-operated Gwadar port in the Pakistan's south

Previous studies on CPEC discusses about employment, trade, energy expansion, development of Gwadar port, good governance in Pakistan etc. (Xie, 2015; Yunjiao, 2015; Ahmed, 2015). Xie, (2015) explained that this CPEC will increase investment opportunities for Pakistani businessmen that will lead Pakistan toward Industrialization and development of under-developed parts of both the countries and also create new labor market for both moreover this ancient silk route will be revitalized with new opportunities for inhabitants of both the countries. Yunjiao, (2015) shed light on the importance of energy cooperation between China Pakistan, CPEC will help to develop regional economies and strengthen energy sector too, a lot of things has been defined in CPEC but still with regard to energy cooperation the mechanisms are vague and there is need of improvement to institutionalize the cooperative mechanism moreover study says that Pakistan is at a good strategic location and this CPEC will help both the economies in different way.

This paper is organized in the following ways. First part discusses the overall impotence of CPEC for both countries Pakistan and China and second part sheds light on the opportunities of tourism through CPEC.

\section{China-Pakistan Economic Corridor (CPEC)}

China-Pakistan Economic corridor (CPEC) is an agreement to launch joint working group underneath national reforms and de velopment commission of China and Ministry of Planning, reforms and de velopment of Pakistan. This agreement is made to build roadway from Kashgar to newly developing Gwadar port which help China in their trade and Pakistan to give new infra structure, development and connection of rural areas of both the countries. Initially, China had approved the investment in Pakistan's infrastructure and power projects worth $\$ 46$ billion in 2014. Following the increase China has approved additional financing for infrastructure projects in Pakistan under (CPEC), hence taking the overall investment to $\$ 54$ billion from $\$ 46$ billion. In this project China will invest USD 54 Billion in Pakistan in the two important sectors of energy and infrastructure (Xie, 2015).

The CPEC will start from Kashghar (Chinese city) and will go up to Gwadar (Pakistan). Gwadar is a deep sea port which will connect China through Pakistan with Dubai, Oman and other European and African countries. Through Gwadar port the import bill of China would be declined significantly for importing oil from gulf countries as China import $80 \%$ of its crude oil through Persian Gulf route which is more than 6 times larger. Figure 1 clearly explains how this route will make the trade easy for China as the distance for trade will reduce 
from nearly 13000 to $2000 \mathrm{~km}$, moreover this will give access China to newly de veloping Gwadar port. In the first phase of development existing routes will be improved then later on new infrastructure of roads and air trains will be built with billions of investments. First trade through CPEC has been started from $31^{\star}$ October 2016 (Dawn.com, Chowdhery, 2014; Ranjan, 2015).

\subsection{Importance of CPEC for China}

CPEC is a conjointly valuable project for both countries, and its direct and immediate benefit to the mainland China will be in huge reduction of shipping costs to the Europe and Middle East (Anwar, 2011; Zafar, 2014). Pakistan will charge the fee from China for the transportation of goods through CPEC (Vélez, 2015). If Pakistan succeeds in providing a suitable environment to China in relocating its labor intensive industries, the country would gain more. This investment in longer run will be helpful to develop an improved education, health, and skill indicators systems of the country (Faheemullah, et al., 2016)

- Reduction in mileage: Presently, the cumulative distance of 19,132 miles is covered by the land goods to be shipped to the Europe from central China. After the completion of CPEC, this cumulative distance would be decreased to 9,579 miles, of which 7,847 miles will be through sea, and 1,750 by land (distance from Karachi to central China).

- Reduction in time used: Similarly, the time required to transport the goods from the current route to the CPEC route would also be reduce by $50 \%$ from 50 days to 25 days.

- Reduction in freight charges: The freight charges of a 40 feet container would be reduced from $\$ 2,500$ to $\$ 1000$. Which result in 50-65\% reduction in freight charges. The shipment to and from the Middle Eastern countries would also gain substantial benefits in transportation costs and time. The distance between central China and Middle East would thus be reduced by 80 per cent (Hao, 2015).

- Reduction in transportation cost: The reduced distance would also cut the cost of transportation. For now, freight charges from Abu Dhabi to Shanghai are $\$ 2,000$ for a 40 feet container. It takes 16 days to reach the destination from this route (Wang et.al., 2014). These charges would reduce to $\$ 200-250$ per 40 feet container when CPEC route becomes operative, and the time taken to reach the destination would be 2-3 days. CPEC would also provide the shortest and most cost effective route for landlocked Afghanistan to China, India and Indian Ocean. The distance would be approximately 600 kilometers less as compared to the other nearest port of Chabahar (Lin, 2015).

\subsection{Importance of CPEC for Pakistan}

CPEC will transfer Pakistan into a regional economic hub and it will boost the confidence of investors not only from China but also from other parts of the world. CPEC will also provide telecommunications and energy infrastructure to Pakistan to overcome the power crisis (Table 1).

Table 1. Projects approved under CPEC in energy, transport and infrastructure

\begin{tabular}{|c|c|c|c|}
\hline $\begin{array}{l}\text { CPEC Projects } \\
\text { Portfolio }\end{array}$ & $\begin{array}{c}\text { Phase I } \\
\text { (Short term 2014-2018) }\end{array}$ & $\begin{array}{c}\text { Phase II } \\
\text { (Medium term 2014-2030) }\end{array}$ & $\begin{array}{c}\text { Phase III } \\
\text { (Long term term 2014-2030/proposals) }\end{array}$ \\
\hline Infrastructure & $\begin{array}{l}\text { - } 2500 \mathrm{~km} \text { highways } \\
\text { - } 411 \mathrm{~km} \text { railways } \\
\text { - Orange metro line, Lahore } \\
\text { - Feasibility report of } 6600 \mathrm{~km} \\
\text { railway }\end{array}$ & $\begin{array}{l}\text { - } 3000 \mathrm{~km} \text { highways } \\
\text { - } 1872 \mathrm{~km} \text { railways } \\
\text { - Mass transit, Quetta, Karachi, } \\
\text { Lahore, Peshawar } \\
\text { - Feasibility report of } 5200 \mathrm{~km} \\
\text { railway }\end{array}$ & $\begin{array}{l}\text { - } 4000 \mathrm{~km} \text { highways } \\
\text { - } 7000 \mathrm{~km} \text { of new and upgraded } \\
\text { railways } \\
\text { - Road and railway link to China, Iran, } \\
\text { Afghanistan, and to Central Asia and } \\
\text { Turkey }\end{array}$ \\
\hline Energy & $\begin{array}{l}\text { - } 10,400 \mathrm{MW} \text { electricity by } 2018 \\
\text { - } 17,045 \mathrm{MW} \text { electricity by } 2022 \\
\text { - Transmission line } 4000 \mathrm{MW}\end{array}$ & $\begin{array}{l}\text { - } 17,045 \text { MW electricity by } 2018 \\
\text { - Gawadar Nawabshah gas pipe line }\end{array}$ & $\begin{array}{l}\text { - } 10,400 \text { MW electricity by } 2018 \\
\text { - Gawadar Kashgar oil pipe line }\end{array}$ \\
\hline Industry & $\begin{array}{l}\text { Feasibility study for } 3 \text { industrial } \\
\text { parks }\end{array}$ & $\begin{array}{l}\text { - } 8 \text { Economic zones } \\
\text { - Steel mils at Gawadar and Chiniot }\end{array}$ & $\begin{array}{l}\text { - } 39 \text { Economic zones } \\
\text { - } 21 \text { Mineral processing unit }\end{array}$ \\
\hline Gawadar & $\begin{array}{l}1.5 \text { billion USD development } \\
\text { project }\end{array}$ & $\begin{array}{l}\text { - Gawadar port } \\
\text { - Gawadar international airport } \\
\text { - Gawadar industrial park } \\
\text { - Gawadar city Master plan }\end{array}$ & $\begin{array}{l}\text { - Gawadar planned city } \\
\text { - Gawadar industrial park } \\
\text { - Real estate/housing schemes }\end{array}$ \\
\hline Other projects & $\begin{array}{l}\text { Fiber optical cable from Kasghar } \\
\text { to Rawalpindi }\end{array}$ & Feasibility study for port keti bandar & $\begin{array}{l}\text { - Fiber optical cable from Rawalpindi to } \\
\text { Karachi } \\
\text { - New cities along the CPEC }\end{array}$ \\
\hline Total cost & 46 billion USD & 54-80 billion USD & 80-150 billion USD \\
\hline
\end{tabular}

*Source: Planning Commission of Pakistan 


\subsection{Geographical Importance}

Geographical position of Pakistan has attracted global powers in the pursuit of their political, economic, and energy interests. In east, Pakistan borders India, Afghanistan in the West, China in northwest, Iran in the Southwest and huge Arabian Sea in the South. Via CPEC, Pakistan will link the Middle East and the central Asian countries to the China and India. In future, opportunities to provide a transit route to landlocked countries like, Afghanistan and central Asian are possible to link these countries to the international market through the Arabian Sea (Anwar, 2011).

- Development of Gwadar port: Developing Gwadar port will give more benefits to the Pakistan and China (Khan, 2013), as it is strategically located at the confluence of Southwest and South Asia, with central Asia not far away. Gwadar is at the mouth of the Persian Gulf which handles 35\% of global seaborne and around $43 \%$ of Chinese oil trade. Gwadar is also near Iran and has the opportunity for overland access. An agreement between Iran and Pakistan is already in place to build an oil refinery at Gwadar (BP, 2014). Iran is interested in obtaining more shares in the international oil markets through Gwadar (Zafar, 2015).

- Development of potential markets: Gwadar port will be operational by the end of this year and China has e ven started their first convoy through CPEC on October $31^{\text {st }}$, 2016. Firstly, the major export of the port was fishing industry available there that provide more improvement and employment to the people of desperately poor Baluchistan. There is need for development of those regions and market which are less developed and it turns out to have high growth potential then the others, Speidell in his book said these markets as frontier markets that have high potential of growth but are not in consideration of many investors Speidell (2011). Hence Gwadar port will open new avenues of development both for Pakistan and China which will develop more trade through CPEC to and from middle-east, Europe and Africa.

- Promoted Tourism: Development of CPEC will lead to de velopment of infrastructure, which will also positively impact the tourism in Pakistan. As Pakistan is full of natural beauty of Swat, Naran, Kaghan, Muree etc. As more and new infrastructure of railways and roads will be de veloped it will not only enhance the trade but also boast the other things such as employment, tourism, development of rural areas and connection of rural areas to urban parts.

CPEC is considered a game changer which is expected to transmute economic growth and it will bring capital into Pakistan. These types of mega project need security and smoothness to run if something will go wrong that will be a massive hindrance in the growth and prosperity of Pakistan. In short, the main propositions of the CPEC for Pakistan are summarized below.

- To promote the harmony and friendship in the region

- To cope on terrorism, drug trafficking and other organized crime

- To reinforce the relation between Eurasian Economic Community and Shanghai Cooperation Organization

- To encourage the trade assistance

\section{Tourism in Pakistan}

The Tourism industry in Pakistan has gone through period of robust growth and bust, from its heyday during the 1970s when the country received unprecedented amounts of foreign tourists, thanks to the Hippie trail (Paracha, Nadeem (2008). In 2016, the number of foreign tourists visiting Pakistan was 965,498. If we compare, then almost 50 million domestic tourists make short trip to various locations of Pakistan usually between May to August. Beside domestic, the tourists from UK, USA, India and china also contributed in tourism inflow (Bush 2010). The country's attraction ranges from the ruin of the Indus Valley Civilization such as Mohenjodaro, Harappa and Taxila, to the Himalayan hill stations, which attract those interested in winter sports. Pakistan is home to several mountain peaks over $7000 \mathrm{~m}$, which attracts adventurers and mountaineers from around the world, especially K2. The north part of Pakistan has many old fortresses, ancient architecture and the Hunza and Chitral valley, home to small pre-Islamic Animist Kalash people community. The romance of the historic Khyber Pakhtunkhwa province is timeless and legendary, Punjab province has the site of Alexander's battle on the Jhelum River and the historic city Lahore, Pakistan's cultural capital, with many examples of Mughal architecture such as Badshahi Masjid, Shalimar Gardens, Tomb of Jahangir and the Lahore Fort. Important tourist destinations and their peculiar features are summarized in Table 2. 
There are six main cultural sites in the Pakistan which are categorized as UNESCO World Heritage:

- Archaeological Ruins at Mohenjodaro

- The ruins of Taxila

- The ancient fort of Rohtas

- The Kabule Gate

- The Lahore Fort and Shalimar Gardens in Lahore

- $1^{\text {st }}$ Century Buddhist Ruins at Takht-i-Bahi and Neighboring City Remains at Sahr-i-Bahlol

- Historic Monuments of the ancient city of Thatta

Gilgit Baltistan is considered to be the capital of tourism in Pakistan. It has the range of some of the highest mountains in the world, including $\mathrm{K} 2$, which is the second highest mountain in the world. Highly rich in landscape, mountains, glaciers, lakes, and valleys, Gilgit Baltistan is also famous for its landmarks, culture, history, and people.

Table 2. Popular tourist destinations and their features

\begin{tabular}{|c|c|c|c|c|c|c|c|c|}
\hline No & $\begin{array}{l}\text { Tourist } \\
\text { s spots } \\
\end{array}$ & Elevation-\& Climatic & Attractive Features & Accommodation & Accessibility & $\begin{array}{l}\text { Culture/ } \\
\text { Festivals }\end{array}$ & Facilities & $\begin{array}{l}\text { Location, } \\
\text { Province }\end{array}$ \\
\hline 1 & $\begin{array}{l}\text { Gilgit } \\
\text { valley }\end{array}$ & $\begin{array}{l}1500 \mathrm{~m}- \\
\text { Cool desert climate, } \\
\text { extended winters } \\
\text { and brief summers }\end{array}$ & $\begin{array}{l}\text { Most spectacular region of } \\
\text { Pakistan in terms of its } \\
\text { geography and scenic beauty } \\
\text { because the world's three } \\
\text { mightiest mountain ranges } \\
\text { the Karakaram, the Hindo } \\
\text { kuch and the Himalays meet } \\
\text { there. Trophy Hunting }\end{array}$ & 66 hotels & $\begin{array}{l}\text { By air, By } \\
\text { road, (cars, } \\
\text { jeeps, buses) }\end{array}$ & $\begin{array}{l}\text { Multi } \\
\text { cultural \& } \\
\text { lingual } \\
\text { people, } \\
\text { Babusar } \\
\text { polo } \\
\text { festival, } \\
\text { harvesting } \\
\text { festival, } \\
\text { Shandur } \\
\text { polofestival }\end{array}$ & $\begin{array}{l}\text { Public transport, } \\
\text { Mobile access, } \\
\text { Shopping } \\
\text { markets, } \\
\text { Restaurants, } \\
\text { Hospital, } \\
\text { Pharmacy }\end{array}$ & $\begin{array}{l}\text { Gilgit } \\
\text { Baltistan }\end{array}$ \\
\hline 2 & Chitral & $\begin{array}{l}1517 \mathrm{~m} \text { - } \\
\text { Mediterranean } \\
\text { climate with warm } \\
\text { summers \& cold } \\
\text { winters }\end{array}$ & $\begin{array}{l}\text { Beautiful landscape, } \\
\text { captivating and majestic } \\
\text { Hindukush range, steep } \\
\text { harsh mountains and lush } \\
\text { green valleys }\end{array}$ & $\begin{array}{l}21 \text { hotels ranging } \\
\text { from high end } \\
\text { luxury hotels to } \\
\text { very low priced } \\
\text { motels }\end{array}$ & $\begin{array}{l}\text { By air, By } \\
\text { road, (cars, } \\
\text { jeeps, buses) }\end{array}$ & $\begin{array}{l}\text { Ancient } \\
\text { kalash } \\
\text { culture }\end{array}$ & $\begin{array}{l}\text { Public transport, } \\
\text { Mobile access, } \\
\text { Shopping } \\
\text { markets, } \\
\text { Restaurants, } \\
\text { Hospital, } \\
\text { Pharmacy, Banks }\end{array}$ & KPK \\
\hline 4 & $\begin{array}{l}\text { Naran } \\
\text { valley }\end{array}$ & $\begin{array}{l}2500 \mathrm{~m}- \\
\text { Cold in winters with } \\
\text { significant snowfall } \\
\text { and mild cold in } \\
\text { summers with } \\
\text { heavy rainfall }\end{array}$ & $\begin{array}{l}\text { Virtual paradise, } \\
\text { Hima-lay an peaks hidden } \\
\text { with clouds or snow several, } \\
\text { beautiful fairy tale lakes like } \\
\text { Saifulmalook lake, Ansu } \\
\text { lake, Saral lake, Babusar top } \\
\text { and Noori top attract tourists } \\
\text { for hiking and trekking }\end{array}$ & $\begin{array}{l}\text { More than } 100 \\
\text { hotels ranging from } \\
\text { luxury to low priced } \\
\text { hotels }\end{array}$ & $\begin{array}{l}\text { By road, } \\
\text { (cars, jeeps, } \\
\text { buses) }\end{array}$ & $\begin{array}{l}\text { Pakhtun } \\
\text { culture }\end{array}$ & $\begin{array}{l}\text { Public transport, } \\
\text { Mobile access, } \\
\text { Shopping } \\
\text { markets, } \\
\text { Restaurants, } \\
\text { Hospital, } \\
\text { Pharmacy, Banks }\end{array}$ & KPK \\
\hline 5 & $\begin{array}{l}\text { Neelam } \\
\text { valley }\end{array}$ & $\begin{array}{l}4000 \mathrm{~m}- \\
\text { Chills and heavy } \\
\text { snowfall in winters } \\
\text { but becomes } \\
\text { charming and cool } \\
\text { in summers }\end{array}$ & $\begin{array}{l}\text { Long bow shaped thick } \\
\text { forest region, Neelam river, } \\
\text { dozens of historical places } \\
\text { like Sharda peeth and } \\
\text { Janwai town is one of the } \\
\text { most beautiful and historical } \\
\text { places in Neelam }\end{array}$ & 31 hotels & $\begin{array}{lr}\text { By road } \\
\text { (cars, jeeps, } \\
\text { buses) }\end{array}$ & $\begin{array}{l}\text { Kashmiri } \\
\text { culture, } \\
\text { Traditional } \\
\text { sport kabddi } \\
\text { festival }\end{array}$ & $\begin{array}{l}\text { Public transport, } \\
\text { Mobile access, } \\
\text { Shopping } \\
\text { markets, } \\
\text { Restaurants, } \\
\text { Hospital, } \\
\text { Pharmacy } \\
\end{array}$ & $\begin{array}{l}\text { Azad } \\
\text { Kashmir }\end{array}$ \\
\hline 6 & Kalaam & $\begin{array}{l}2001 \mathrm{~m}- \\
\text { Humid subtropical } \\
\text { climate }\end{array}$ & $\begin{array}{l}\text { Lush green hills , thick } \\
\text { forests, mesmeric lakes, } \\
\text { meadows and waterfalls and } \\
\text { worth seen features of } \\
\text { landscape, large number of } \\
\text { alpine glacial lakes like } \\
\text { Mahodand lake and Kundol } \\
\text { lake, also attracts tourists for } \\
\text { paragliding }\end{array}$ & 32 hotels in kalaam & $\begin{array}{lr}\text { By road, } \\
\text { cars, jeeps, } \\
\text { buses) }\end{array}$ & $\begin{array}{l}\text { Pakhtun } \\
\text { culture, } \\
\text { Kalaam } \\
\text { summer } \\
\text { festival }\end{array}$ & $\begin{array}{l}\text { Public transport, } \\
\text { Mobile access, } \\
\text { Shopping } \\
\text { markets, } \\
\text { Restaurants, } \\
\text { Dispensary }\end{array}$ & KPK \\
\hline 7 & Arangkel & $\begin{array}{l}2554 \mathrm{~m}- \\
\text { Warm in summers } \\
\text { and cold in winters }\end{array}$ & $\begin{array}{l}\text { Lush green village, hill } \\
\text { station and attracts tourists } \\
\text { for hiking }\end{array}$ & Nil & $\begin{array}{ll}\text { By } & \text { road } \\
\text { (jeeps) } & \end{array}$ & $\begin{array}{l}\text { Kashmiri } \\
\text { culture }\end{array}$ & $\begin{array}{l}\text { Public transport, } \\
\text { Mobile access, } \\
\text { Dispensary }\end{array}$ & $\begin{array}{l}\text { Azad } \\
\text { Kashmir }\end{array}$ \\
\hline 8 & $\begin{array}{l}\text { Abbottaba } \\
\text { d }\end{array}$ & $\begin{array}{l}1256 \mathrm{~m}- \\
\text { Humid subtropical } \\
\text { climate with mild to } \\
\text { warm summers and } \\
\text { heavy rain \& snow }\end{array}$ & $\begin{array}{l}\text { Hill station bounded at all } \\
\text { four sides by the Sarban } \\
\text { hills from which the tourists } \\
\text { can take breathtaking views }\end{array}$ & 58 hotels & $\begin{array}{l}\text { By road, } \\
\text { (bikes, cars, } \\
\text { jeeps, buses), } \\
\text { \& highways }\end{array}$ & $\begin{array}{l}\text { Spring } \\
\text { festival, } \\
\text { Hazara } \\
\text { cultural } \\
\text { festivals, }\end{array}$ & $\begin{array}{l}\text { Public transport, } \\
\text { Mobile access, } \\
\text { Shopping } \\
\text { markets, } \\
\text { Restaurants, }\end{array}$ & KPK \\
\hline
\end{tabular}




\begin{tabular}{|c|c|c|c|c|c|c|c|c|}
\hline & & fall in winters & & & & $\begin{array}{l}\text { folk music } \\
\text { festivals }\end{array}$ & $\begin{array}{l}\text { Hospitals, } \\
\text { Pharmacy, Banks }\end{array}$ & \\
\hline 9 & Peshawar & $\begin{array}{l}359 \mathrm{~m}- \\
\text { Semi-arid climate, } \\
\text { very hot summers } \\
\text { and relatively cold } \\
\text { winters }\end{array}$ & $\begin{array}{l}\text { Historical city, attractive for } \\
\text { historical places like Khyber } \\
\text { pass and Balahisar fort, food } \\
\text { streets, amusements etc. }\end{array}$ & 73 hotels & $\begin{array}{l}\text { By air, By } \\
\text { road, (bikes, } \\
\text { cars, jeeps, } \\
\text { buses), \& } \\
\text { motorway }\end{array}$ & $\begin{array}{l}\text { Afghan } \\
\text { cultural, } \\
\text { afghan } \\
\text { musicians } \\
\text { and art } \\
\text { culture }\end{array}$ & $\begin{array}{l}\text { Public transport, } \\
\text { Mobile access, } \\
\text { Shopping } \\
\text { markets, } \\
\text { Restaurants, } \\
\text { Hospitals, } \\
\text { Pharmacy, Banks }\end{array}$ & KPK \\
\hline 10 & $\begin{array}{l}\text { Lahore } \\
\text { (Metropoli } \\
\text { tan City) } \\
\text { Capital } \\
\text { city of } \\
\text { province } \\
\text { Punjab. }\end{array}$ & $\begin{array}{l}217 \mathrm{~m}- \\
\text { Semi-arid climate }\end{array}$ & $\begin{array}{l}\text { Historical city, reached } \\
\text { height of its splendor under } \\
\text { Mughal empire and famous } \\
\text { for its ancient architecture, } \\
\text { city of gardens, food streets, } \\
\text { theme parks, zoo, theaters, } \\
\text { amusements etc. }\end{array}$ & $\begin{array}{l}119 \text { hotels, motels, } \\
\text { etc. ranging from } \\
\text { luxury to low priced } \\
\text { accommodation. }\end{array}$ & $\begin{array}{l}\text { By air, By } \\
\text { road (bikes, } \\
\text { cars, jeeps, } \\
\text { buses), \& } \\
\text { Motorway }\end{array}$ & $\begin{array}{l}\text { Mughal } \\
\text { culture, Sufi } \\
\text { festivals, } \\
\text { Basant, } \\
\text { Horse \& } \\
\text { cattle show } \\
\text { festival }\end{array}$ & $\begin{array}{l}\text { Public transport, } \\
\text { Mobile access, } \\
\text { Shopping } \\
\text { markets, } \\
\text { Restaurants, } \\
\text { Hospitals, } \\
\text { Pharmacy, Banks }\end{array}$ & Punjab \\
\hline 11 & Skardu & $\begin{array}{lrr}2228 \mathrm{~m}- & \\
\text { Moderate } \\
\text { summers } \\
\text { extreme cold } \\
\text { winters }\end{array}$ & $\begin{array}{l}\text { Attracts tourists and trekkers } \\
\text { because of highest peaks, } \\
\text { mountains, glaciers, } \\
\text { camping and adventures }\end{array}$ & 12 hotels & $\begin{array}{l}\text { By air, By } \\
\text { road (buses, } \\
\text { cars, jeeps) }\end{array}$ & $\begin{array}{l}\text { Skardu polo } \\
\text { festival, Silk } \\
\text { route } \\
\text { festival }\end{array}$ & $\begin{array}{l}\text { Public transport, } \\
\text { Mobile access, } \\
\text { Dispensary }\end{array}$ & $\begin{array}{l}\text { Gilgit } \\
\text { baltistan }\end{array}$ \\
\hline 12 & $\begin{array}{l}\text { Gojal } \\
\text { valley }\end{array}$ & $\begin{array}{l}4877 \mathrm{~m}- \\
\text { Chill and cold } \\
\text { winters with snow } \\
\text { fall and mild warm } \\
\text { summers }\end{array}$ & $\begin{array}{l}\text { Borders Pakistan and China } \\
\text { at Khunjerab Pass, } \\
\text { mountainous region forming } \\
\text { the western part of the } \\
\text { Karakoram and eastern } \\
\text { Pamir mountain range, lofty } \\
\text { ice-capped peaks, roaring } \\
\text { rivers, lush green pastures } \\
\text { and long glaciers }\end{array}$ & 24 hotels & $\begin{array}{l}\text { By } \\
\text { road(buses, } \\
\text { cars) }\end{array}$ & $\begin{array}{l}\text { Wakhi and } \\
\text { Burusho } \\
\text { culture, } \\
\text { Ginani } \\
\text { festival }\end{array}$ & $\begin{array}{l}\text { Public transport, } \\
\text { Mobile access, } \\
\text { Dispensary }\end{array}$ & $\begin{array}{l}\text { Gilgit } \\
\text { baltistan }\end{array}$ \\
\hline 13 & $\begin{array}{l}\text { Deosai } \\
\text { plains }\end{array}$ & $\begin{array}{l}4114 \mathrm{~m}- \\
\text { Heavy snowfall in } \\
\text { winters and mild } \\
\text { cold summers }\end{array}$ & $\begin{array}{l}\text { Covers the boundary of } \\
\text { Karakoram and western } \\
\text { Himalayas, Sheosar lake one } \\
\text { of the highest lakes in the } \\
\text { world, deep blue water with } \\
\text { snow covered mountains in } \\
\text { background and greenery } \\
\text { with wild flowers in } \\
\text { summers offer such a } \\
\text { charming view to the } \\
\text { visitors, Deosai national } \\
\text { park, camping }\end{array}$ & 12 hotels & $\begin{array}{l}\text { By } \\
\text { road(jeeps) }\end{array}$ & $\begin{array}{l}\text { Deosai } \\
\text { festival }\end{array}$ & $\begin{array}{l}\text { Public transport, } \\
\text { Mobile access }\end{array}$ & $\begin{array}{l}\text { Gilgit } \\
\text { baltistan }\end{array}$ \\
\hline 14 & $\begin{array}{l}\text { Muzaffara } \\
\text { bad }\end{array}$ & $\begin{array}{l}737 \mathrm{~m}- \\
\text { Chill and cold } \\
\text { winters and warm } \\
\text { summers }\end{array}$ & $\begin{array}{l}\text { Breath taking beauty located } \\
\text { at the junction of Neelam } \\
\text { river and Jehlum river, } \\
\text { attracts tourists because of } \\
\text { its scenic beauty, velvet } \\
\text { green plateaus and } \\
\text { wonderful climate, Red fort } \\
\text { is the witness of ancient } \\
\text { history of Muzaffarabad, Pir } \\
\text { chanassi due to its } \\
\text { tremendous scenic beauty, } \\
\text { velvet green plateaus and } \\
\text { wonderful climate it wins } \\
\text { admiration of nature lovers }\end{array}$ & $\begin{array}{l}27 \text { hotels ranging } \\
\text { from high end } \\
\text { luxury hotels to low } \\
\text { priced hotels }\end{array}$ & $\begin{array}{l}\text { By air, By } \\
\text { road(buses,ca } \\
\text { rs,jeeps0 }\end{array}$ & $\begin{array}{l}\text { Kashmiri } \\
\text { culture, } \\
\text { Spring } \\
\text { festival, } \\
\text { Paragliding } \\
\text { festival }\end{array}$ & $\begin{array}{l}\text { Public } \\
\text { transport ,Mobile } \\
\text { access, Shopping } \\
\text { markets, } \\
\text { Restaurants, } \\
\text { Hospital, } \\
\text { Pharmacy, Banks }\end{array}$ & $\begin{array}{l}\text { Azad } \\
\text { Kashmir }\end{array}$ \\
\hline 15 & Siri Paye & $\begin{array}{l}3000 \mathrm{~m}- \\
\text { Heavy snowfall in } \\
\text { winters and } \\
\text { occasional hail } \\
\text { storm and heavy } \\
\text { rains in summer }\end{array}$ & $\begin{array}{l}\text { Spectacular beauty of its } \\
\text { mountains, glaciers and lush } \\
\text { greenery, peaceful } \\
\text { environment, amazing and } \\
\text { beautiful landscape also } \\
\text { attracts tourists for hiking, } \\
\text { blend of pure nature and } \\
\text { alpine milieu, thriving wild } \\
\text { flowers beds unrivalled } \\
\text { beauty of snow covered } \\
\text { peaks is out-worldly }\end{array}$ & 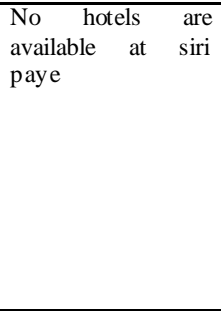 & $\begin{array}{ll}\text { By road, } \\
\text { (jeeps, horse } \\
\text { riding, } \\
\text { hiking) }\end{array}$ & $\begin{array}{l}\text { Pakhtun } \\
\text { culture }\end{array}$ & $\begin{array}{l}\text { Mobile access, } \\
\text { Local food }\end{array}$ & KPK \\
\hline
\end{tabular}

According to Table 2, fifteen tourist attractions has been recommended through the questionnaire and ratings from the online tourist websites. Authors emphasized the most popular tourist's attraction which are linked with CPEC route. In this table authors pointed out the top attraction for tourism department, tourist service providers, and tourists who can choose a place according to their choice and interests, because authors tried to get latest information about the destination and its feature, popular tourist destinations and their attractive features, accommodation, accessibility, culture/ festivals, facilities, location. Trough Table 2, one can easily find the most important information about the attraction which is useful for readers and for new researcher. When tourists want to travel, this kind of tables are more helpful instead of searching through many websites which might not accurate, so here they can safe their time. These kind of tables should be in tourist spots by the government and on the all tourist websites. 


\section{Tourism opportuni ties through CPEC (from Khunjrab Pass to Gawadar) via Silk Road}

Beside other advantages, tourism which is an important industry that will also see an immense boost as a result of CPEC in Pakistani. Pakistan has the range of some of the highest mountains in the world, including K2, highly rich in landscape, mountains, glaciers, lakes, and valleys, and also boasts another five peaks above 8,000 meters, in addition to the more than 50 other mountains over 7,000 meters. Mountaineers from around the globe will flock to Pakistan as soon as CPEC is operational.

Increased Chinese investment in tourism sector of Pakistan via CPEC, after the building of road and railways to connect the two countries, this projects will generate new investment opportunities;

"We are planning consultations with Pakistani companies on developing joint tourism products," said by president of Yema Group Company Limited, Mr. Chen Qiang.

Recently in 2015, more then 30 million tourists traveled to the Xinjiang province of China," he said. From Xinjiang province, a group of people visited the Gilgit Baltistan to explore the opportunities for joint tourism and mutual businesses.

"Special efforts are being made to set up a Pakistani pavilion in the park where individuals, including cooks, singers and artisans will be brought from Pakistan and given employment."

2.5 million tourists both domestic and international travelled to northern areas in Pakistan last year. The tourism destinations could be extended to Xinjiang and other destinations both in China and Pakistan via CPEC. The 700-kilometre long coastal areas of Arabian Sea can be made accessible to the tourists via Kashgar-Gwadar road. A bus service is working from the Chinese border to Gilgit-Baltistan. Later on, transportation would be available for other cities of China like Kashgar and Urumqi, while both cities are already connected via air route. Urumqi is considered to be the first stop for goods coming from Central Asia to China, as a large number of people from Pakistan, especially businessmen visit Xinjiang daily.

Being a tourism paradise CPEC is expected to boost the tourism industry in Pakistan, especially in Gilgit-Baltistan. The region is considered to be a mountaineer's paradise, since it is home to five of the 'eight-thousands' (peaks above 8,000 meters), as well as more than 50 mountains over 7,000 meters. It is also home to the world's second highest peak K2 and the Nanga Parbat. Gilgit-Baltistan, also known as 'The Jewel of Pakistan', and rightly so, the region holds some of the most breath-taking views in the world, from the highest peaks in the world and the most number of glaciers in the world, to the most magnificent lakes in the world. Apart from the beauty, the region holds significant strategic importance, it borders Pakistan with China and will act as a gateway for the rest of Pakistan once China-Pakistan-Economic-Corridor is completed.

With improving security situation in the rest of the country and better infrastructure, tourism is expected to grow.

"For a few years now, between 10,000 and 20,000 tourists would visit Gilgit-Baltistan each year but in 2015, over 600,000 people visited Gilgit-Baltistan and this year, it is expected that around one million people will travel to GB," GB Tourism Secretary Jehanzeb".

\section{Security Measurements}

The Parliamentary Committee on China Pakistan Economic Corridor (CPEC) was informed that a Special Security Division (SSD) comprising 9,000 Pakistan Army soldiers and 6,000 para-military forces personnel has been set up for the security of the project and individuals working on it.

"Special Security Division has been entrusted with the duty of protecting Chinese workers and projects under CPEC," officials of ministry of defense said while briefing the parliamentary panel on Friday.

The government has also allocated Rs1.3 billion for CPEC security in addition to the efforts of provincial governments, the committee was informed. "Apart from security on land, the government has also taken relevant initiative through the maritime security agency to protect the coast as well as through the Pakistan Air Force," added the officials.

Tourist companies also can connect private security guard's firms, although it's not economical. But for the time being they can start and in furniture like Pakistani forces are dealing with security issues, there tourist companies can business better without security.

\section{Trade in Local Currency}

A recent development made between China-Pakistan trades is to eliminate the hurdle of currency while making trade. As most of the business done between Pakistan and China were transacted in dollar terms. But now two countries want to lessen the influence of USD in the trade. Central bankers proposed to do trade in the local 
currencies. This roadshow is not only with Pakistan. China is already doing the same strategies with other countries. In this regard Regional Standard Chartered banks are playing their role to conduct trade in the local currencies and implemented these policies with middle-east and Africa in recent days. Until now China agreed with eight countries to do trade in their local currencies. These countries include Pakistan, Hong Kong, Qatar, and UAE.

China is doing this roadshow after the announcement of Special Drawing Rights (SDR) list of global currencies by IMF which is effective from October 1, 2016. This strategy of local currency will work with the currently going investment in Pakistan by China worth $\$ 54$ billion for the China-Pakistan economic corridor (CPEC). Infrastructure in Pakistan will be built under this agreement of local currencies but it all depends that how quickly this information speckled to businessmen said by the Carmen Ling, a Managing director of the bank's delegation to Pakistan (Siddiqui, 2016).

In Africa, Asia and middle-east more than $60 \%$ Standard Chartered's are benefited from the initiative of local currency. This initiative of Pakistan China trade for building infrastructure and other projects will also encourage exchange of trade partnership and strengthen the ties which will not only fortify the trade and on-going projects but also affect the tourism industry in Pakistan. Pakistan also need to focus on this side of benefit in order to get turnover from this part too. As in all these projects it is less focused to be benefited from tourism too.

\section{Chinese Tourists: A Target Market for Pakistan Tourism Industry?}

Since the dramatic reform and opening up of China's economy, more and more Chinese citizens are traveling abroad to visit, travel and consume products around the world. According to China Tourism Research Institute, in 2016, with income growth and tourist consumption upgrade, as well as as well as visa, flight and other convenient factors, China's outbound tourism heat continued. The number of China's outbound tourists reached 122 Million in 2016, increasing by $4.3 \%$ compared to the year of 2015 with 117 million outbound tourists. China has remained the world's largest number of outbound tourists for consecutive years. The outbound percentage of people as compare to previous years are presented in Figure 2.

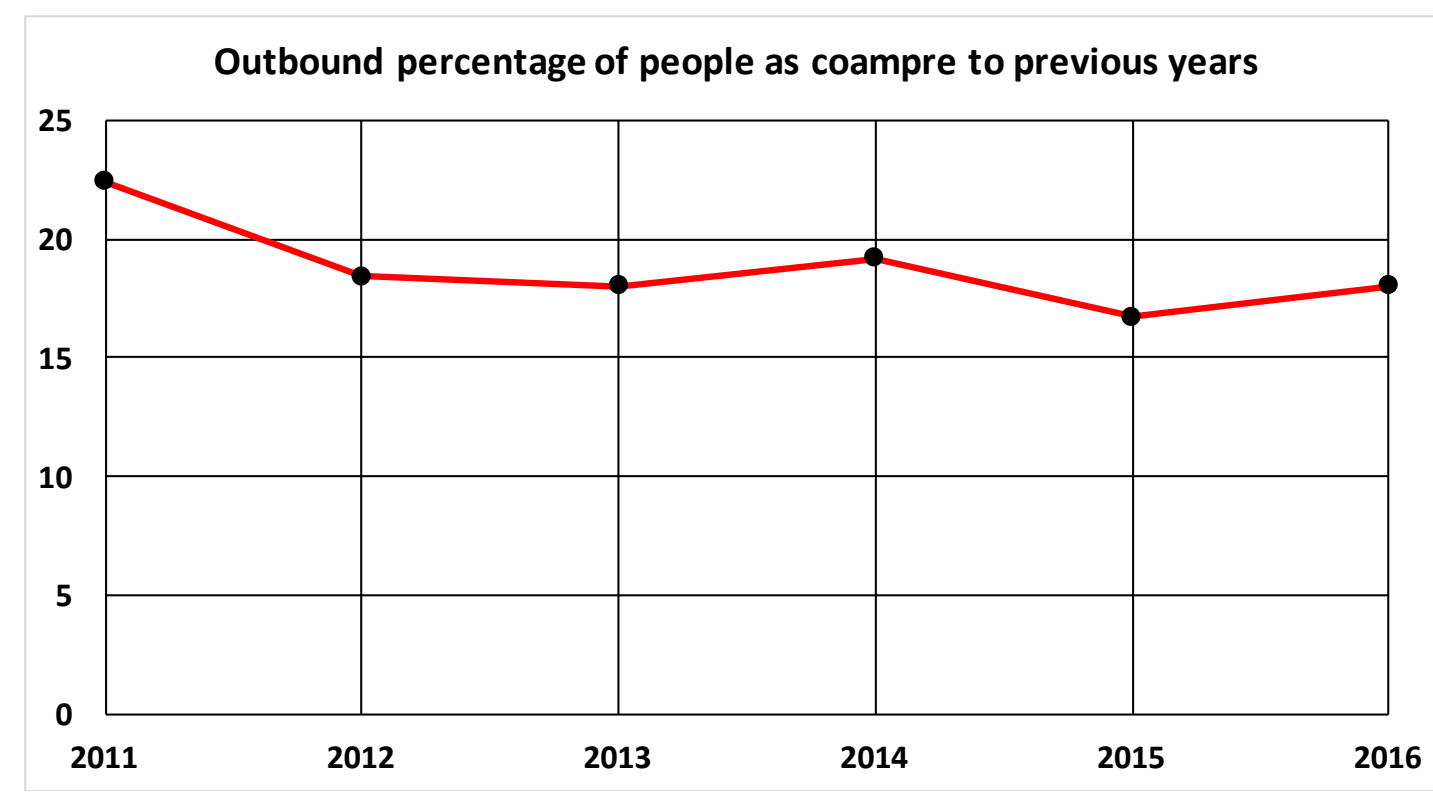

Figure 2. The outbound percentage of people as compare to previous years

(a) Chinese tourists are a major driving force in the global tourism industry so understanding the unique features and needs of Chinese visitors is key. Adapting to this emerging market can be confusing for many foreign travel agencies and companies. The Chinese have unique, special needs and travel habits that need to be understood and catered for.

(b) Chinese have higher disposable incomes and also have a huge desire for international products and brands, this all lead to this significant consumer spending abroad. Being very keen for shopping; it is their priority during their travelling. Also people with large family and social circle, want to bring home numerous souvenirs for them. As per Telegraph report, the Chinese tourists spend nearly 650 pounds (\$1000) on average on foreign high streets. 
(c) $46 \%$ of the Chinese tourists, travel for business purpose. For them, efficiency and the quality of business related services are more important like; high speed internet access, 24-hour easy food delivery, online ticket booking services.

(d) $31 \%$ of the total outbound tourism, is for Leisure purpose from China. They mostly often travel in groups suing tour companies. These companies organize group travel. Also many Chinese citizens do not speak English, so they like to travel in groups.

(e) Mostly tour companies take care of everything including visas.

(f) Travelling for Chinese people is a new thing, and most of them have ne ver travelled abroad, so they are less eager to explore alone.

(g) The Chinese live in a more collective, communist society where people are used to doing things in groups.

\section{Trend of China Outbound Tourism}

Based on the surveys conducted by tour agencies in China, the outbound tourism will see a considerable growth due to appropriate visa policies, extensive summer holiday travel peak, and operation of more international flights between Pakistan and China. Also, with the implement of "One Belt and One Road" approach this year, the outbound tourism market of China will have endowed with more opportunities. As per report, $\mathrm{n}$ the fourth quarter of 2015, travel agencies organized 13.8385 million visitors to foreign countries, an escalation of $29.19 \%$ over the same period in 2014.

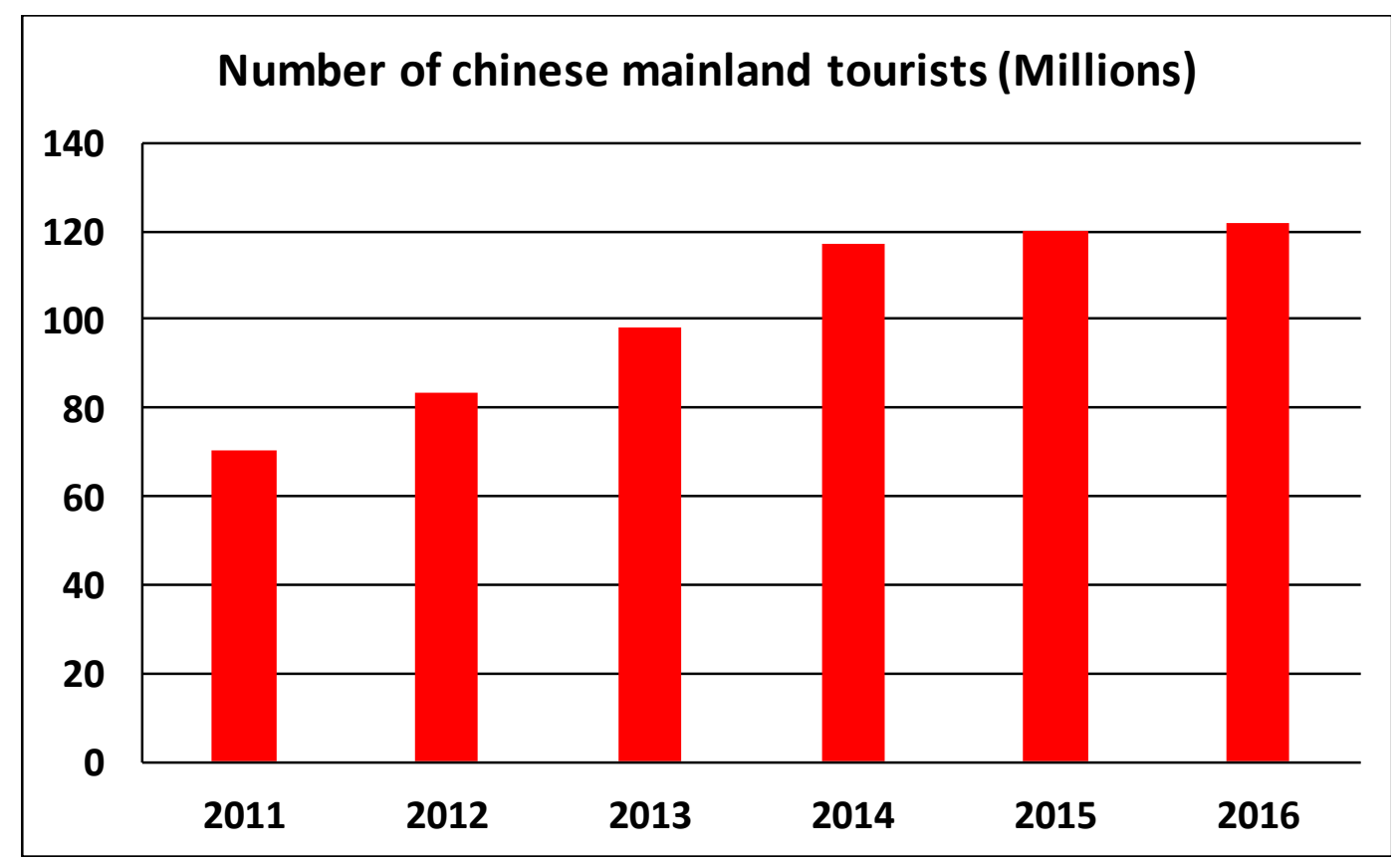

Figure 3. The number of Chinese tourists in recent years

\section{Impact of CPEC on Chinese Tourists Vising Pakistan}

Pakistan had received a37 \% increase in tourism visa application submitted by Chinese in the semester of 2016. Previously, despite the close relations between China and Pakistan, the country in South Asia did not attract too many international tourist arrivals due to security reasons. The visits paid by Chinese outbound tourists would keep growing in the following years, mainly because CPEC, the report added.

- Pakistan has also turned into a favorite tourism destination for Chinese people along with the business, being executed under CPEC or 'One belt one road'. Ultimately, this promoted the 'People-to-people' interactions among the people of both countries. Huge increase in Chinese people traveling to Pakistan has been observed in the recent year, mainly, they are engaged in the CPEC-related projects. According to a survey, there has been around 100 percent increase in the traveling index on both sides last year.

- The CPEC involved many Chinese companies doing business in Pakistan, and on other hand Chinese government provided some additional opportunities to Pakistani youth to visit China for education. 
According to an estimate, there was a big raise in scholarships' ratio provided to Pakistani students during the last two years. In the wake of new development, Cultural and social changes were also on the rise.

- Pakistani entrepreneurs were also being encouraged to set up their business Houses in China, which has emerged as World largest economic hub. Chinese visa's policy was relaxed for this purpose.

- Another Chinese businessman Tan She said the massive traveling of Chinese people is because of improved security situation and better investment opportunities in Pakistan in the recent years adding that now we feel more safe and comfortable in our brotherly country.

- With the launching of CPEC-based projects, Pakistan has become one of the most favorite business destinations for China and Central Asian States. Both Pakistani and Chinese leadership believes that CPEC would help Pakistan to strengthen its economy and it would be a fate-changer for improving the living conditions of the people.

\section{Pakistan Government Role in Boosting Tourism in Country}

The tourism industry anywhere can be improved by providing safety to the people (foreigners as well as the locals) who wants to visit a specific location. That's the very basic step. Secondly, by positive publicity of the places where people will definitely want to go. There comes the Tourism Department in Pakistan, they must work for it and run advertisements on television and newspapers. Pakistan is blessed with beautiful landscapes and has a lot to offer for the tourists. But from the past two decades, we lost this tourism industry due to the war on terror, and so many beautiful places and buildings have been destroyed. The Tourism department must work now to improve the infrastructure over there and and work on the tourist-visiting spots, to counter the losses been done.

\section{Concluding Remarks}

CPEC will provide new avenues of development, connection tourism and trade for Pakistan and China. It connects Chinese city of Kashgar with newly establishing Gwadar port via silk road which will be fully functional by the end of 2016. The major focus of this CPEC connection via Silk Road is trade, energy and development of rural areas of Pakistan which also reflects to tourism directly and indirectly. Pakistan should more focus on the importance of tourism through CPEC. It will de velop the tourism industry in Pakistan as Pakistan is full of natural beauty and has diverse weather in it and the same time Chinese businessmen can be target market for tourist attraction on Silk Road.

Pakistan is home of most stunning Himalayan peaks, including K-2 and various magnificent valleys. It has beautiful Arabian Sea, deserts, Indus valley, ancient Buddha's civilization carved in its mountains and historic forts. With all this it is supposed to be one of the world's greatest tourist destinations. But due to weak travel and tourism framework, low branding and marketing effectiveness and deduced priority given to the travel and tourism industry by the government, Pakistan had left behind among other countries around the globe. By improvising the ongoing projects, and also focusing ton preserving the natural environment like many other countries, will not only attract more tourists but also would play a role model in the world as a cause in support on global issues.

\section{References}

Ahmed, M. (2015). China-Pakistan Economic corridor: A Test of Good Governance in Pakistan. International Conference on CPEC at GC University Lahore, December, 09-10-2015.

Anwar, Z. (2011). Development of infrastructural linkages between Pakistan and Central Asia Pakistan-Central Asia linkages. Research Journal of South Asian Studies, 26, 103-115.

Austin, B. (Unknown). Pakistan Travel Information and Travel Guide. Lonely Planet. Retrieved 27 September 2010.

BP. (2014). Statistical Review of World Energy.

Chowdhery, R. D. (2014). Sea change in oil security. http://stratrisks.com/geostrat/ 16499>2014 [accessed 01.01.14].

Ebrahim, Z. (2016). China-Pakistan Economic corridor: A boon for the economy, a bane for locals, dawn.com. http://www.dawn.com/news/1236159

Faheemullah, S., Qiang, J., \& Ying, F., (2016). Prospects of Pakistan-China Energy and Economic Corridor. Renewable and Sustainable Energy Reviews, 59, 253-263. https://doi.org/10.1016/j.rser.2015.12.361 
Fazil, M. (2015). The Chin-Pakistan Economic corridor: Potential and Vulnerabilities.

Hao, H, Geng, Y., Li, W., \& Guo, B. (2015). Energy consumption and GHG emissions from China's freight transport sector: scenarios through 2050. Energy Policy, 85, 94-101. https://doi.org/10.1016/j.enpol.2015.05.016

"International tourism, number of arrivals | Data | Table". data.worldbank.org. Retrieved 2016-06-17.

Khan, S. A. (2013). Geo-economic imperatives of Gwadar Sea Port and Kashgar economic zone for Pakistan and China. IPRI J, XIII(2), 87-100.

Lin, W., Chen, B., Xie, L., \& Pan, H. (2015). Estimating energy consumption of transport modes in China using DEA. Sustainability, 7, 4225-4239. https://doi.org/10.3390/su7044225

Memon, A. (2015). Pak-China trade: Importance of negotiating the FTA, Express tribune.

Paracha, N. (7 July 2008). "Before the Lights Went Out". http://nadeemfparacha.wordpress.com. Karachi.

Ranjan, A. (2015). The China-Pakistan economic corridor: India's options. New Delhi; 2015.

Siddiqui, S. (2016). Pakistan China to trade in local currencies. Express tribune.

Speidell, L. (2011). Frontier Market Equity Investing: Funding the Winners of the future. Research foundation of CFA Institute.

Vélez, F. (2015). From the Suez to the Panama Canal and Beyond: Gamal Abdel Nasser's influence in Latin America, Varia Historia, 31(55), 163-191.

Wang, Y. F., Li, K. P., Xu, X. M., \& Zhang, Y. R. (2014), Transport energy consumption and saving in China. Renew Sustain Energy Review, 29, 641-655. https://doi.org/10.1016/j.rser.2013.08.104

Xie, X., Ma, C., \& Li, J. (2015). Research on employment Opportunities under the framework of China Pakistan Economic Corridor, International Conference on CPEC at GC University Lahore December 09-10-2015.

Yunjiao, X., \& Guowei, Z. (2015). Strengthening Energy Cooperation between China and Pakistan in CPEC, International Conference on CPEC at GC University Lahore December 09-10-2015.

Zafar, B. (2015). Gwadar Port: Pakistan, China all set to develop master plan 2014 http://tribune.com.pk/story/671852/gwadar-port-pakistan-china-all-set-to-develop-master-plan/ [accessed 01.01.14].

Websites:

http://thediplomat.com/2015/05/the-china-pakistan-economic-corridor-potential-and-vulnerabilities/

http://tribune.com.pk/story/1220159/bilateral-commerce-pakistan-china-trade-local-currencies/

http://tribune.com.pk/story/943392/pak-china-trade-importance-of-negotiating-the-fta/

http://www.gilgitbaltistan.gov.pk/DownloadFiles/TrophyHunting.pdf

http://pakistanguides.com/hunting/

http://www.hunzaadventuretours.com/hunting-tours.html

\section{Copyrights}

Copyright for this article is retained by the author(s), with first publication rights granted to the journal.

This is an open-access article distributed under the terms and conditions of the Creative Commons Attribution license (http://creativecommons.org/licenses/by/4.0/). 